\title{
Tema dan Pola Pengembangan Paragraf dalam Artikel Opini di Harian Umum Pikiran Rakyat
}

\author{
Rini Suryalies Fairini ${ }^{1)}$ \\ Universitas Indraprasta PGRI
}

Jalan Nangka No. 58 C/TB. Simatupang, Tanjung Barat, Jakarta Selatan 12530

\author{
Sumaryoto ${ }^{2)}$ \\ Universitas Indraprasta PGRI \\ Jalan Nangka No. 58 C/TB. Simatupang, Tanjung Barat, Jakarta Selatan 12530 \\ Bambang Sumadyo ${ }^{3)}$ \\ Universitas Indraprasta PGRI \\ Jalan Nangka No. 58 C/TB. Simatupang, Tanjung Barat, Jakarta Selatan 12530 \\ rini.suryalies@gmail.com ${ }^{1)}$
}

\begin{abstract}
This study aims to determine the theme and pattern of paragraph development in opinion articles in the May 4-5 June 2020 edition of the General Pikiran Rakyat Daily. The approach used in this research is descriptive qualitative. This research technique uses descriptive analysis. This technique was chosen because the authors considered the objectives, focus and sub-focus of the study. The results of this study indicate a variety of themes and patterns of paragraph development. The paragraph development pattern is closely related to choosing a theme to produce an interesting and easy-to-understand article. Thus, these two things can be used as an alternative in choosing learning sources or reading materials to increase interest and reading and writing skills for students in particular, as well as society in general.
\end{abstract}

Keywords: Themes, Paragraph Development Patterns, Opinion Articles, Pikiran Rakyat.

\begin{abstract}
Abstrak
Penelitian ini bertujuan untuk mengetahui tema dan pola pengembangan paragraf dalam artikel opini di Harian Umum Pikiran Rakyat edisi 4 Mei - 5 Juni 2020. Pendekatan yang digunakan dalam penelitian ini adalah deskriptif kualitatif. Teknik penelitian ini menggunakan analisis deskriptif. Teknik ini dipilih karena penulis mempertimbangkan tujuan, fokus, dan subfokus penelitian. Hasil penelitian ini menunjukkan adanya keberagaman tema dan pola pengembangan paragraf. Pola pengembangan paragraf sangat erat kaitannya dengan pemilihan tema untuk menghasilkan artikel yang menarik dan mudah dipahami. Dengan demikian, kedua hal tersebut dapat dijadikan alternatif pemilihan sumber belajar atau bahan bacaan untuk meningkatkan minat dan keterampilan membaca serta menulis bagi peserta didik khususnya, juga masyarakat pada umumnya.
\end{abstract}

Kata Kunci: Tema, Pola Pengembangan Paragraf, Artikel Opini, Pikiran Rakyat

\section{PENDAHULUAN}

Bahasa adalah ucapan, pikiran, dan perasaan seseorang yang teratur antara angguta masyarakat, berupa simbol bunyi yang dihasilkan oleh alat ucap menusia 
yang fungsi utamanya adalah berkomunikasi, bernteraksi (fungsi sosial) menyampaikan pikiran atau menyatakan diri, konsep, gagasan juga perasaan (fungsi ekspresi). Selain itu, bahasa sebagai alat komunikasi manusia untuk menyampaikan pesan menjadi hal penting untuk dikuasai. Untuk itu pembelajaran bahasa di sekolah terutama pembelajaran bahasa Indonesia tentu menjadi salah satu sentral yang harus diperhatikan keberhasilan pembelajarannya.

Bahasa khususnya bahasa Indonesia yang merupakan alat komunikasi yang menjadi jembatan penyampaian ide gagasan dan pola komunikasi masyarakat menjadi suatu hal yang penting untuk dikuasai. Ini jelas berhubungan dengan penguasaan empat kerterampilan berbahasa yaitu menyimak, berbicara, membaca dan menulis. Jadi jelaslah bahwa pembelajaran bahasa Indonesia di sekolah harus mengarah pada penguasaan empat keterapilan berbahasa yaitu keterampilan menyimak, berbicara, membaca dan menulis yang terintegrasi dan terimplikasi pada penyelesaian masalah sosial yang dihadapi peserta didik.

Salah satu kompetensi kebahasaan yang akan lebih jauh dipaparkan dalam penelitian ini adalah kompetensi membaca dan menulis. Masyarakat Indonesia dalam hal membaca atau minat membaca masih memerlukan usaha yang sungguhsungguh untuk meningkatkan nya. Rendahnya minat baca ini mendorong kita mencoba memperhatikan faktor penghambat tersebut dengan berupaya mencari alternatif bahaan bacaan yang menarik dan memberikan inovasi kreatif dalam proses pembelajaran, salah satunya menuntut guru mata pelajaran Bahasa Indonesia untuk terus berpikir kreatif mencoba inovasi-inovasi untuk mencari solusi dari masalah tersebut.

Kreativitas guru untuk menyajikan dan mengemas pembelajaran membaca dan menulis jelas akan berpengaruh pada ketertarikan siswa dan bermuara pada keberhasilan siswa menguasai keterampilan tersebut. Gerakan literasi yang membahana diawal hingga sekarang seperti tersisa sayup-sayup sampai tentu perlu upaya lain yang lebih mengena dan langsung berpengaruh pada siswa hingga masyarakat umum jika dapat. Dengan demikian, minat baca dan literasi bangasa Indonesia secara umum dapat ditingkatkan.

Permendiknas No. 37 Tahun 2018 tentang Silabus dan RPP Kurikulum 2013 Revisi pun telah mengaplikasikan hal ini dengan memuat silabus dengan mencantumkan keterampilan menulis hampir dalam setiap KD Pemilihan sumber belajar dalam kegiatan pembelajaran bahasa Indonesia di sekolah tentu menjadi salah satu cara agar keberhasilan penguasaan keterampilan membaca dan menulis siswa dapat lebih mudah dicapai. Menyajikan dan memilih sumber pembelajaran yang kekinian dan sesuai dengna apa yang sedang terjadi di masyarakat tentu akan membuat pembelajaran lebih menarik. Salah satu kompetensi dasar yang diisyaratkan Kurikulum 2013 Revisi untuk pembelajaran Bahasa Indonesia di kelas XII SMA yaitu memahami konsep tema dan pola pengembangan paragraf dan menulis artikel.

Tema adalah dasar sebuah cerita atau pandangan hidup yang membangun gagasan utama dalam suatu karya (Rusyana, 1988). Pendapat lain, tema adalah sesuatu yang menjadi persoalan atau pikiran utama. (Esten, 1990). Dengan demikian, tema menjadi hal yang penting pada proses mengembagkan paragraf. 
Artikel sebagai karya tulis populer yang ditulis di media massa merupakan salah satu sumber belajar yang tampaknya cukup mengasyikan karena keberagaman tema dan isinya yang kekinian diharapkan bisa membuat siswa lebih tertarik. Hakim (2008:44-50) berpendapat bahwa beberapa unsur-unsur artikel yang harus ada seperti kata, kalimat, gaya bahasa dan isinya. Unsur-unsur yang ada akan membentuk karakteristik artikel yang harus digunakan.

Suyitno (2011: 154) menyatakan bahwa artikel harus memenuhi beberapa syarat, yaitu: 1) Interest: syarat pertama adalah tema itu harus menarik dimata penulis. Dengan demikian kamu akan melakukan semuanya dengan maksimal yang akhirnya tulisan juga maksimal. 2) Memiliki Keahlian: seperti yang sudah saya sampaikan, tulisan harus memberikan manfaat bagi orang lain. dan untuk memberikan sesuatu yang bermanfaat, penulis artikel harus ahli dibidang tersebut, jadi syarat yang kedua adalah kamu harus memiliki keahlian dibidang tersebut. 3) Data Tersedia: sebagai bahan tulisan tema harus didukung oleh data. 4) Ruang Lingkup: gunakan tema sebagai instrumen yang membuat kerjaan penulis artikel lebih mudah. Maksudnya, dapat menggunakan tema sebagai ruang lingkup.

Memilih artikel sebagai sumber belajar tampaknya dapat mengalihkan sedikit perhatian siswa dari literasi digital melalui jejaring sosial saja. Salah satunya artikel opini yang terdapat di Harian Pikiran Rakyat. Artikel opini pada harian tersebut sebagai salah satu media massa yang memiliki ruang lingkup cukup luas yaitu wilayah provinsi Jawa Barat dan Banten.

Merujuk pada silabus mata pelajaran Bahasa Indonesia versi Kurikulum 2013 revisi mata pelajaran Bahasa Indonesia ternyata memiliki Kompetensi Dasar yang mengarah pada penguasaan konsep artikel yang di dalamnya memuat tentang konsep paragraf serta pola pengembangan paragraf. Oleh karena itu, penelitian tentang tema dan pola pengembangan paragraf dalam artikel di Harian Umum Pikiran Rakyat edisi 8 Mei-5 Juni 2020 ini diharapkan mampu menghasilkan simpulan yang menjadi salah satu alternatif sumber pembelajaran bagi siswa SMA kelas XII, khususnya dan masyarakat pada umumnya. Upaya ini pun dapat menjadi awal mengajak kembali membaca secara fisik tidak hanya membaca secara daring dari ebook atau surat kabar online saja sehingga gerakan literasi kembali menggema menuju terwujudnya masyarakat Indonesia yang literat.

Tarigan (2008: 28) mengemukakan lima jenis pola pengembangan paragraf, yaitu paragraf perbandingan, paragraf pertanyaan, paragraf sebab-akibat, paragraf contoh, dan paragraf perulangan. Namun, Wiyanto (2004: 69) mengemukakan bahwa ada tujuh jenis pengembangan paragraf, yaitu menerangkan, merinci, contoh, bukti, pertanyaan, perbandingan, dan sebab akibat. Sejalan dengan hal tersebut, Rahardi (2009: 172) menyampaikan bahwa terdapat tujuh pola pengembangan paragraf, yaitu pola runtutan ruang dan waktu, pola sebab-akibat, pola susunan pembanding, pola susunan ibarat, pola susunan daftar, pola susunan contoh, dan pola susunan bergambar. Sementara itu, menurut Chaer (2011:88), pengembangan paragraf dapat dengan: contoh, definisi, pemerincian, ilustrasi, kronologi, sebab-akibat, perbandingan atau pengontrasan, repetisi, klasifikasi, dan analogi. 


\section{METODE}

Penelitian ini menggunakan pendekatan deskriptif kualitatif karena cocok digunakan untuk menganalisis unsur yang ada di dalam sebuah artikel yang menjadi fokus penelitian. Menurut Whitney (dalam Nazir, 2014: 43), penelitian deskriptif adalah pencarian fakta dengan interpretasi yang tepat. Penelitian ini bertujuan membuat deskripsi secara sistematis, faktual, dan akurat. Bogdan dan Taylor (dalam Moleong, 2006: 4) berpendapat bahwa penelitian kualitatif adalah prosedur penelitian yang menghasilkan data deskriptif berupa kata-kata tertulis atau lisan dari orang-orang dan perilaku yang diamati.

Teknik penelitian ini menggunakan analisis deskriptif. Teknik ini dipilih karena penulis mempertimbangkan tujuan serta fokus dan subfokus penelitian. Teknik analisis deskriptif ini dinilai mampu menjawab rumusan masalah serta diharapkan mampu mencapai tujuan penelitian.

Penelitian ini berfokus pada artikel opini dalam Harian Umum Pikiran Rakyat edisi 4 Mei sampai dengan 5 Juni 2020. Penulis memilih fokus tersebut dengan pertimbangan data yang dianalisis cukup mudah ditemukan mengingat situasi karantina Covid-19 yang menyebabkan sedikit terkendala mencari data penelitian yang akurat dalam masa karantina pandemik ini. Subfokus penelitian ini adalah tema dan pola pengembangan paragraf dalam artikel opini di Harian Umum Pikiran Rakyat edisi 4 Mei-5 Juni 2020. Dengan pertimbangan unsur tema dan pola pengembangan paaragraf adalah unsur pembangun sebuah artikel yang sangat penting dan perlu dianalisis.

Arikunto (2013: 203) menjelaskan bahwa instrumen penelitian adalah alat yang digunakan peneliti dalam mengumpulkan data agar pekerjaannya lebih mudah dan hasilnya lebih baik, lebih cermat, lengkap, dan sistematis. Oleh karena itu, penulis menggunakan human instrument atau dengan kata lain menjadikan penulis sendiri sebagai instrumen penelitian untuk memahami, menganalisis dan mendeskripsikan fokus dan subfokus peneliatain sebagai data penelitian kualitatif ini. Hal ini sejalan dengan paparan tentang instrumen bahwa peneliti sebagai instrumen penelitian maksudnya peneliti merupakan perencana, pelaksana pengumpulan data, analis, penafsir data, dan pada akhirnya menjadi pelapor hasil penelitian (Moleong, 2006: 168).

Teknik yang digunakan pada penelitian ini yaitu teknik catat. Menurut Sudaryanto (2015: 205) teknik catat adalah proses pencatatan pada kartu data yang selanjutnya diikuti dengan klasifikasi. Selain itu, penulis juga menggunakan teknik simak bebas libat. Sejalan dengan pendapat Mahsun (2007: 92), metode simak adalah metode penyediaan data yang digunakan untuk memperoleh data dengan menyimak penggunaan bahasa. Teknik simak bebas libat ini peneliti hanya berperan sebagai pengamat penggunaan bahasa oleh informannya, peneliti tidak terlibat dalam peristiwa pertuturan yang bahasanya sedang diteliti, dan penelitit tidak berperan menentukan pembentukan dan pemunculan calon data (Mahsun, 2007: 93).

Berdasarkan metode simak bebas libat cakap dan metode catat, prosedur pengumpulan data pada penelitian ini dilakukan dalam enam tahap. Pertama, peneliti mengumpulkan harian umum Pikiran Rakyat edisi 4 Mei-5 Juni 2020. 
Kedua, peneliti mencari tulisan artikel opini di dalamnya. Ketiga, tulisan artikel opini diurutkan berdasarkan jadwal terbit. Keempat, peneliti membaca dan menandai paragraf artikel opinitersebut. Kelima, peneliti membuat tabel data. Keenam, peneliti mencatat data yang telah dikumpulkan pada tabel data yang telah dibuat.

Adapun langkah-langkah yang digunakan peneliti untuk menganalisis data, meliputi: memberikan kode di setiap artikel dan di setiap paragraf artikel opini, mengidentifikasi tema dan pengembangan dalam setiap paragraf artikel opini, mencatat hasil identifikasi tema dan pola pengembangan paragraf dalam tabel, mendeskripsikan hasil temuan yang berupa pola pengembangan paragraf pada artikel opini surat kabar harian Pikiran Rakyat.

Peneliti melakukan teknik pemeriksaan keabsahan data (triangulasi) data dalam penelitian ini agar data yang diteliti dapat diketahui dengan pasti kebenarannya. Triangulasi merupakan teknik pemeriksaan keabsahan data yang memanfaatkan sesuatu yang lain di luar data itu untuk keperluan pengecekan atau sebagai pembanding terhadap data itu (Moleong, 2006: 330). Dalam penelitian ini, peneliti melakukan triangulasi penyidik. Moleong (2006: 331) mengungkapkan bahwa triangulasi dengan teknik penyidik berarti peneliti memanfaatkan peneliti atau pengamat lain untuk keperluan pengecekan kembali derajat kepercayaan data. Langkah yang dilakukan peneliti dalam triangulasi mencari ahli bahasa. Dalam hal ini ahli Bahasa tersebut adalah Bapak Drs. Dedeng Ahmad Rahmani, M.Pd. sebagai pengawas Pembina di SMAN 1 Purwakarta. Selanjutnya peneliti memberikan semua data hasil penelitian untuk diuji keabsahannya kepada beliau.

\section{HASIL DAN PEMBAHASAN}

Dalam penelitian ini penulis menemukan beberapa temuan dan analisis terhadap fokus dan subfokus penelitian sebagai berikut:

1. Artikel pertama dengan kode A01 terdiri atas 19 paragraf karena itu deskripsi subfokus satu yaitu tema artikel A01 adalah tidak tepatnya bantuan penanganan Covid-19 oleh pemerintah. Deskripsi untuk subfokus kedua yaitu pola pengembangan paragraf untuk A01 adalah menggunakan pola pengembangan paragraf umum-khusus pada A01-P1 dan A01-P2 dan A01-P3.

Wabah Covid-19 secara radikal telah mengubah dimensi social kultural kita. Pada kelas menengah metropolitan situasi yang paling mencekam adalah psikologi kecemasan dan keridakpastian. Pada golongan rawan miskin dan kaum miskin, urusannya menukik langsung pada ekonomi. (AO1-P1).

Bicara urusan rakyat, pemerintah yang punya tanggung jawab. Presiden, menteri, gubernur, walikota/ bupati hingga kepala desa sedang ditanang apakah punya kecerdasan sekaligus sikap kemanusiaan dalam melayani rakyatnya. (A01-P2) 
Paragraf lain menggunakan pola pengembangan paragraf pertentangan pada A01-P4, P5 serta AO1-P6 dan P7. Sementara itu menggunakan pola pengembangan paragraf contoh A01-P10 dan A01-P11.

Menangani korban pengungsian berbeda dengan menghadapi pandemic Covid-19. Di situasi pengungsian urusa masak sangat repot. Apalagi harus berburu sayuran segar dan daging segar. Akan tetapi, pada keadaan di rumah saja, memasak adalah bagian dari kegiatan produktif. Ini yang tidak dibaca sebagai analisis sebelum menggulirkan kebujakan public. (AO1-P6).

Sebenarnya kalau kita mau membaca "Pedoman Umum Pembagian Sembako 2020" telah terruang aturan yang cukup bagus. Pedoman yang ditandatangani Menteri Koordiantor Bidang Pembangunan Manusia dan Kebudayaan, selaku ketua Tim Pengendalai Pelaksaan Penyaluran Bantuan Sosial Nontunai Desember 2019 tersebut, antara lain menyeburkan, "Tidak boleh digunakan untuk pembelian minyak, tepng terigu, gula paasir, MPASI pabeikan makanan kalieng, mi instan dan bahanpangan lainnya yang tidak termasuk dalam butie a-d di atas. Bantuan juga tidak boleh digunakan untuk pembelian pulsa dan rokok. (A01-P7)

Jadi, jelas terlihat bahwa dalam satu artikel yang sama terdapat pola pengembangan paragraf yang berbeda-beda secara variatif mendukung gagasan penulis artikel mengembangakan tema artikelnya.

2. Artikel kedua dengan kode A02 terdiri atas 21 paragraf karena itu deskripsi subfokus satu yaitu tema artikel A02 adalah dampak pandemik Covid-19. Deskripsi untuk subfokus kedua yaitu pola pengembangan paragraf untuk A02 adalah menggunakan pola pengembangan paragraph umum-khusus dalam sebagian besar paragrafnya yaiu A02-P1, P2, P10, P11. Untuk A02-P3 dan P8 menggunakan pola pengembangan paragraf perbandingan. Semntara untuk A02P4, P14, P15, P19, P20 menggunakan pola pengembangan sebab-akibat.

Menurut keterangan para ahli, seberulnya tingkat kematian korbanCovid-19 masih lebih rendah dibandingkan akibat birus Marburg, Ebola dan H5N1. Namun, mengapa wabah corona sampai berdampak luar biasa tehadap peningkatan kemiskinan? (A02-P3)

Menurut Prof. Dr. Sri Hartini, guru besar penyakit dalam di Universitas Padjajaran, peningkatan kemiskinan akibat pandemi di Indonesia intinya terjadi karena keterlambatan dalam mencegah pandeminya. (AO2-P4).

Sekali lagi, wabah birus corona masih mungkin terus mengancam penambahan penduduk miskin. Olh sebab itu, pemerintah diimbau untuk sering menginisiasi kajian atau penelitian yang bekaitann dengan masker lengkap yang murah dan efektif. Yang dimaksud dengan masket lengkap adalah masker yang sekaligus emmiliki alat pelindung mata pencegah virus. (AO2-P19) 
3. Artikel ketiga dengan kode A03 terdiri atas 14 paragraf karena itu deskripsi subfokus satu yaitu tema artikel A02 adalah Keteladan tokoh Muhammad Nu'man Somantri. Deskripsi untuk subfokus kedua yaitu pola pengembangan paragraf untuk A03 adalah menggunakan pola umum-khusus pada AO3-P1, P2, $\mathrm{P} 3$. Selain itu, menggunakan pola pengembangan sebab-akibat untuk AO3-P4, P5 serta menggunakan pola pengembangan kronologis untuk AO3-P10 sampai P13 dan diakhiri dengan paragraf kesimpulan.

Bagi keluarga besar UPI, almarhum tak sekadar dipandang sebagai Rektor IKIP (sebelum berganti nama) perriode1978-1987. Beliau tercatat sebagai pimpinan ke-6 Kampus Bumi Siliwangi sejak bernama PTPG Bandung. Akan tetapi, jejak langkah, sumbangsih serta berbagai program dan kebujakan selama hamper dua decade emimpin kampus pencetak par guru itu, telah membawa rintisan bagi kemajuan IKIP pada periode-periode selanjutnya. (AO3-P2).

Karena nilai-nilai yang memberi teladan itulah, seperti yang dikatakan tokoh pendidik Amerika Wiliam A Ward, para pemberi inspirasi adalah guru yang agung. Jelas, Prof Nu'man Somantri bukan pendidik yang biasabiasa saja karena sekadar menyampaikan materi pelajaran. (A03-P4).

Namun, hanya segelintir orang yang tahu bahwa organisasi yang berkiprah dalam bidang seni tadidional (Sunda) itu secara formal didirikan di Kedutaan Besar Republik Indonesia (KBRI) di kota Bonn, ibukota Republik Federal Jerman, pada 1 Oktober 1985.

Selain itu, salah seorang inisiator dan pendiri Kabumi adalah mendiang Prof. Nu'man. Bagi Pak Nu'man kelahiran Kabumi sekaligus menjawab tantangan banyak pihak yang menyebutkan masyarakat Eropa pada umumnya hanya mengenal tari Jawa dan Bali sebagai citra seni budaya Indonesia. (A03-P11-12)

4. Artikel keempat dengan kode A04 terdiri atas 12 paragraf karena itu deskripsi subfokus satu yaitu tema artikel A04 adalah kisah hidup tokoh Ujun. Deskripsi untuk subfokus kedua yaitu pola pengembangan paragraf untuk A04 adalah menggunakan pola pengembangan umum-khusus untuk A04-P1, P2, P3, P11P12, sedangkan untuk A04-P9-10 menggunakan pola pengembangan kronologis dan A04-P7-8 menggunakan pola pengembangan paragraf ilustrasi.

Laki-laki setengah abad itu, sehari-harinya harus tidur dan tinggal dengan sepuluh ekor kambing. Antara kamar dengan kandang kambing hanya disekat bamboo. Posisinya berada tepat di atas kandang kambing. (A04-P2).

Kondisi tersebut membuat bau kotoran kambing tak bisa dihindari sehingga aroma tak sedap itu pun selalu tercium setiap saat. Kendati seperti itu, Ujun tidak bisa berbuat apa-apa. (A04-P3). 


\section{Diskursus: Jurnal Pendidikan Bahasa Indonesia}

Vol. 3, No. 3, Desember 2020, pp. 250-260

p-ISSN: 2615-4935

e-ISSN: 2615-4943

Ia pun mengerti kalau tempat tinggal yang juga kamarnya itu tidak layak huni. Apalagi taka da fasilitas lainnya sama sekali, hanya satu ruangan untuk tmpat tidur, taka da kamarmandi atauun dapur. Kamar yang ditempati Ujun hanya beralaskan tikar kuceal. Itu pun pemberian tetangganya. (A04-P6).

Sebenarnya menurut Ujun, ia pernah memiliki lahan. Namun, lahan miliknya itu telah dijual karena butuh uang mendesak untuk membiayai resepsi pernikahan anaknya.

Setelah lahannya terjual, praktis dia tak memiliki apa-apa sama sekali, termasuk untuk tempat tinggalnya. Malahan ia sempat terlunta-lunta mencari tempat tinggal. "Pilihan terakhir ya Saya menjadikan kandang kambing ini jadi tempat tidur sekaligus tempat tinggal," katanya. (A04-P910)

5. Artikel kelima dengan kode A05 terdiri atas 17 paragraf karena itu deskripsi subfokus satu yaitu tema artikel A05 adalah tradisi mudik. Deskripsi untuk subfokus kedua yaitu pola pengembangan paragraf untuk A04 adalah menggunakan pola pengembangan Umum-khusus pada A05-P1, P2, P12-P17. Sementara itu, A05-P5, P6, P8 dan P9 menggunakan pola pengembangan paragraf definisi.

Mengapa dorongan untuk mudik begitu sangat kuat? Mudik adalah peristiwa budaya yang sudah menjadi tradisi khas menjelang hari besar di Indonesia terutama Idul Fitri. Di beerapa Negara peristiwa emacam ini pun terjadi, misalnya di Cina menjelang Imlek. Masyarakat urban Cina berbondong-bondong kempali ke kampong halamannya (huixiang). (A05P2).

Makna udik berkembang seiring dengan pengaruh bahasa daerah lain, khususnya Jawa sehingga udik kini memiliki beerapa makna; hulu (sungai), atas gunung; desam dusun (Wojowasito,1972); (Badudu-Zain,1994). Udik bermakna pula "darat". Tidak heran jika di lingkyngan masyarakat muncul sebutan orang udik untuk menyebut mereka yang tinggal di darat sebagai kebalilkan bagi orang yang tinggal di laut atau pesisir (Harahap, 1952). A05-P12.

Secara etimologis, mudik terkait erat dengan kata udik. Bentuknya menjadi yang kita kenal dekarang in tidak lepas dari proses gejala bahasa.

Sebagaimana dalam gramatika bahasa Jawa (Kuno), Sunda dan Bali, system pembentukan katanya mengenal afiksasi, antara lain infiksasi. Infiksasi ini cukup unik, bila disisipkan pada kata dasar yang berfonem awal vokal infiks itu berposisi di depan misalnya endog "telur" mendapat infiksasi -ummenjadi umendog "menyerupai telur" (labu masih muda seukuran telur). Demikian pula dengan kata mudik, patut diduga berasal dari umudik yang lama kelamaan mengalami aferensis (penghilangan fonem pada awal kata) menjadi mudik. (A05-P5-6). 
Dinamika meluasnya makna kata (m)udik merupakan gejala yang lazim, seiring dengan berkembangnya peradaban manusia. Kamus Besar Bahasa Indonesia $\mathrm{V}$ daring menjelaskan kata mudik selain (berlayar, pergi) ke udik (hulu sungai; pedalaman) juga sebagai bentuk percakapan dari "pulang ke kampung halaman" (A05-P13)

Deskripsi lengkap tentang temuan dalam analisis tema dan pola pengembangan paragraf dalam artikel opini di harian umum Pikiran Rakyat edisi 4 Mei - 5 Juni 2020 sebagaimana telah penulis paparkan, maka pada bagian ini penulis akan menguraikan penafsiran dari penelitian tersebut.

1. Artikel dalam harian umum Pikiran Rakyat sangat beragam, karena itu pembatasan penelitian yang berfokus hanya pada artikel opini telah membuat fokus penelitian menjadi spesifik dan terarah. Artikel opini ini didisplay selalu pada halaman lima belas yaitu halaman kedua terakhir yang merupakan display strategis dilihat dari teori editing dan layout surat kabar karena praktis menjadi halaman yang mudah dicari dan lebih terjaga karena terletak di lembar kedua. Artikel opini pun dapat mewakili dan tepat menjadi focus karena penelitianii salah satunya bertujuan untuk menemukan alternatif sumber belajar atau bahan bacaaan singkat yang menarik tetapi juga sarat dengan informasi terkini yang sanga penting untuk peningkatan motivasi dan penguasaan keteramppilan membaca dan menuslis masyarakaat pada umumnya atau pelajar khususnya.

2. Tema dalam artikel opini di harian umum Pikiran Rakyat edisi 4 Mei-5 Juni 2020 sangat beragam karena artikel ditulis oleh kolumnis dari berbagai latar belakang walaupun pandemik Covid-19 menjadi issu besar yang menaunginya tetapi disajikan dari berbagai sudut pandang telah sehingga lebih beragam informasi yang didapatkan pembacanya. Ada tema yang secara eksplisit sama dengan judul artikel, adapula tema yang secara implisit hadir menaungi seluruh paparan dalam arti itu.

3. Pola pengembangan paragraf yang digunakan dalam artikel di harian umum Pikiran Rakyat edisi 4 Mei-5 Juni 2020 ini cukup beragam. Dari dua puluh empat artikel yang dianalisis, dua puluh dua artikel membuka paparannya dengan pola pengembangan paragraf umum-khusus. Ada dua artikel saja yang menggunakan pola pengembangan ilustrasi dalam pemaparannya sedangkan semua artikel mengakhiri atau menutup paparannya dengan pola pengembangan paragraf generalisasi. Pada proses pemaparannya artikel yang menjadi fokus penelitian semuanya menggunakan pola pengembangan bervariasi. Membuka dengan umum-khusus dan bervariasi dengan pola pengembangan sebab-akibat, perincian atau pemertentangan dan diakhiri dengan pola pengembangan paragraf generalisi adalah variasi pola pengembangan paragraf yang sering muncul atau digunakan oleh penulis artikel sesuai hasil analisis penulis.

4. Variasi lain yang dipakai penulis artikel dalam fokus penelitian adalah membuka dengan pola pengembangan ilustrasi lalu memaparkan dengna pola pengembangan klasifikasi dan sebab akibat lalu umum-khusus dan tetap menggunakan pola pengembangan paragaraf generalisasi sebagai penutup. 


\section{SIMPULAN}

Berdasarkan hasil dan pembahasan, dapat disimpulkan bahwa tema dalam artikel opini di harian umum Pikiran Rakyat edisi 4 Mei-5 Juni 2020 sangat beragam karena artikel ditulis oleh kolumnis dari berbagai latar belakang walaupun pandemi Covid-19 menjadi issu besar yang menaunginya tetapi disajikan dari berbagai sudut pandang telaah sehingga lebih beragam informasi yang didapatkan pembacanya. Pola pengembangan paragraf sangat erat kaitannya dengan pemilihan tema untuk menghasilkan karya tulis yang menarik dan mudah dipahami. Tema dan pola pengembangan paragraf yang digunakan dalan artikel opini di harian umum Pikiran Rakyat edisi 4 Mei-5 Juni 2020 dapat dijadikan alternatif pemilihan sumber belajar atau bahan bacaan untuk meningkatkan minat dan keterampilan membaca dan menulis bagi pelajar khususnya juga masyarakat pada umumnya.

Adapun saran yang dapat disampaikan ke beberapa pihak, antara lain dalam upaya meningkatkan minat baca serta ketrampilan membaca dan menulis, masyarakatnya hendaknya berusaha lebih keras untuk mencari dan menemuka sumber pembelajaran atau bahan bacan yanga lebih menarik dan mudah dipahami serta sarata denan informasi yang bermanfaat tentunya. Artikel dalam surat kabar dapaat dijadikan salah satu alternatif dalam melakukan upaya tersebut. Masyarakat hendaknya berupaya untuk kembali memilih bahan bacaan yang tidak hanya berupa tampilan daring (online) saja karena literasi hakikatnya literatur cetak seperti buku, surat kabar atau majalah yang memiliki unsur-unsur bacaan yang lengkap menunjang peningkatan keterampilan membaca dan menulis. Guru hendaknya mampu berupaya kreatif dan inovatif selalu menyajikan sumber belajar yang menarik dan kekinian, salahsatunya terdapat dalam artikel opini di surata kabar. Mahasiswa dan civitas akademika di perguruan tinggi pun hendaknya menjadi penggerak yang memungkinkan penelitian terhadap focus dan subfokus penelian yang sama atau relevan dapat dikembangakan lebih luas dan lebih baik lagi.

\section{DAFTAR PUSTAKA}

Arikunto, S. (2013). Prosedur penelitian suatu pendekatan praktik. Jakarta:PT Rineka Cipta.

Chaer, A. (2011). Ragam bahasa ilmiah. Jakarta: PT Rineka Cipta.

Esten, M. (1990). Kesusastraan, pengantar teori dan sejarah. Bandung: Angkasa.

Hakim, M. A. (2008). Kiat menulis artikel di media: Dari pemula sampai mahir. Edisi Revisi. Cetakan IV. Bandung: Nuansa.

Mahsun. (2005). Metode penelitian bahasa. Jakarta: PT Raja Grafindo Persada.

Moleong, L. J. (2006). Metodologi penelitian kualitatif. Bandung: PT. Remaja Rosdakarya.

Nazir, M. (2014). Metode penelitian. Cet. 10. Bogor: Penerbit Ghalia Indonesia.

Rahardi, R. K. (2009). Sosiopragmatik: Kajian imperatif dalam wadah konteks sosiokultural dan konteks situasionalnya. Jakarta: Penerbit Erlangga.

Rusyana, Y. (1988). Perihal kedwibahasaan (Bilingualisme). Bandung: FPS IKIP Bandung. 
Diskursus: Jurnal Pendidikan Bahasa Indonesia

Vol. 3, No. 3, Desember 2020, pp. 250-260

p-ISSN: $2615-4935$

e-ISSN: 2615-4943

Sudaryanto. (2015). Metode dan teknik analisis bahasa. Yogyakarta: Sanata Darma University Press.

Suyitno, I. (2011). Memahami tindakan pembelajaran. Bandung: PT Refika Aditama.

Tarigan, H. G. (2008). Menulis sebagai keterampilan berbahasa. Bandung: Angkasa.

Peraturan Menteri Pendidikan dan Kebudayaan Republik Indonesia Nomor 37 Tahun 2018 tentang Perubahan Atas Peraturan Menteri Pendidikan dan Kebudayaan Nomor 24 Tahun 2016 tentang Kompetensi Inti dan Kompetensi Dasar Pelajaran pada Kurikulum 2013 pada Pendidikan Dasar dan Pendidikan Menengah.

Wiyanto, A. (2004). Terampil menerapkan kaidah ejaan bahasa Indonesia. Gramedia Widiasarana Indonesia. 